\title{
Impact of financial pressure on unemployed job search, job find success and job quality
}

Citation for published version (APA):

Gerards, R., \& Welters, R. (2016). Impact of financial pressure on unemployed job search, job find success and job quality. ROA. ROA Research Memoranda No. 008 https://doi.org/10.26481/umaror.2016008

Document status and date:

Published: 01/01/2016

DOI:

10.26481/umaror.2016008

Document Version:

Publisher's PDF, also known as Version of record

\section{Please check the document version of this publication:}

- A submitted manuscript is the version of the article upon submission and before peer-review. There can be important differences between the submitted version and the official published version of record.

People interested in the research are advised to contact the author for the final version of the publication, or visit the DOI to the publisher's website.

- The final author version and the galley proof are versions of the publication after peer review.

- The final published version features the final layout of the paper including the volume, issue and page numbers.

Link to publication

\footnotetext{
General rights rights.

- You may freely distribute the URL identifying the publication in the public portal. please follow below link for the End User Agreement:

www.umlib.nl/taverne-license

Take down policy

If you believe that this document breaches copyright please contact us at:

repository@maastrichtuniversity.nl

providing details and we will investigate your claim.
}

Copyright and moral rights for the publications made accessible in the public portal are retained by the authors and/or other copyright owners and it is a condition of accessing publications that users recognise and abide by the legal requirements associated with these

- Users may download and print one copy of any publication from the public portal for the purpose of private study or research.

- You may not further distribute the material or use it for any profit-making activity or commercial gain

If the publication is distributed under the terms of Article $25 \mathrm{fa}$ of the Dutch Copyright Act, indicated by the "Taverne" license above, 


\section{Impact of financial pressure on unemployed job search, job find success and job quality}

Ruud Gerards

Riccardo Welters

\section{ROA Research Memorandum}

ROA-RM-2016/8

Researchcentrum voor Onderwijs en Arbeidsmarkt | ROA Research Centre for Education and the Labour Market | ROA 


\title{
Impact of financial pressure on unemployed job search, job find success and job quality
}

\author{
Ruud Gerards \\ Riccardo Welters
}

ROA-RM-2016/8*

May 2016

Research Centre for Education and the Labour Market

Maastricht University

P.O. Box 616, 6200 MD Maastricht, The Netherlands

$\mathrm{T}+31433883647 \mathrm{~F}+31433884914$

secretary-roa-sbe@maastrichtuniversity.nl

www.roa.nl

\footnotetext{
* The ROA Research Memorandum Series was created in order to make research results available for discussion, before those results are submitted for publication in journals.
} 


\section{Abstract \\ Impact of financial pressure on unemployed job search, job find success and job quality**}

Research shows that financial pressure - implied as a consequence of benefit sanctions or exhaustion - prompts the unemployed to intensify their job search. However, there is less agreement about whether that intensified job search produces better quality job outcomes. Building on Self-Determination Theory we posit that financial pressure is a controlled motivator to search for work. Controlled motivators are conducive to goal pursuit (job search activity), yet unfavorable to goal achievement (job search success and job quality). Using the HILDA longitudinal data for Australia, we are able to include direct measures of both financial pressure (cash flow problems and hardship), objective job quality (hourly pay and hours worked) as well as subjective job quality (satisfaction with pay and hours). We find that financial pressure intensifies job search without improving the job find rate and job quality outcomes if a job is secured. Interestingly, if a job is secured the unemployed who searched under financial pressure perceive the job to be of lower quality (in terms of satisfaction with pay and hours worked) even though objectively (in terms of actual pay and hours worked) it is similar to the jobs found by the unemployed who searched without financial pressure. Policy implications are discussed.

JEL classification: J64, J08, J28, J32

Keywords: Job search, job quality, financial pressure, hardship, unemployment, motivation

Ruud Gerards

Maastricht University

ROA

P.O. Box 616

NL-6200 MD Maastricht

The Netherlands

r.gerards@maastrichtuniversity.nl

\author{
Riccardo Welters \\ James Cook University \\ College of Business, Law and Governance \\ AUS-4811 QLD Townsville \\ Australia \\ riccardo.welters@jcu.edu.au \\ and ROA
}

\footnotetext{
** This paper uses unit record data from the Household, Income and Labour Dynamics in Australia (HILDA) survey. The HILDA project was initiated and is funded by the Australian Government Department of Families, Housing, Community Services and Indigenous Affairs (FaHCSIA) and is managed by the Melbourne Institute of Applied Economic and Social Research (Melbourne Institute). The findings and views reported in this paper, however, are those of the authors and should not be attributed to either FaHCSIA or the Melbourne Institute. We thank Ken Mayhew, Andries de Grip, Bert van Landeghem and Ineke Bijlsma for their helpful comments and insights. We also thank the participants of the following conferences and seminars for their questions, comments and insights: James Cook University School of Business Seminar (2015), the ROA poster session (2015), the ROA Human Capital over the Life Cycle conference (2016) and the World Universities Network (WUN) Conference Economics Workshop (2016).
} 


\section{Introduction}

When unemployment insurance (UI) benefits approach exhaustion, the employment hazard rises (Mortensen, 1977; Van den Berg, 1990; Tatsiramos and Van Ours, 2014; Filges, Geerdsen, Knudsen and Jorgensen, 2015). Several studies show that liquidity or wealth effects lead the unemployed to lower their reservation wages or increase their search intensity as their funds run out (e.g. Mortensen, 1986; Bloemen and Stancanelli, 2001; Chetty, 2008). This begs to question the quality of the job matches that arise under financial duress. To assess this job match quality, a relatively small number of recent studies look at wages or employment stability of jobs obtained close to the moment of benefit exhaustion, compared to jobs accepted earlier in the unemployment spell. The most recent studies find that the quality of these job matches is lower (e.g. Gaure, Røed and Westlie, 2012 for Norway; Caliendo, Tatsiramos and Uhlendorff, 2013 for Germany).

However, the aforementioned studies stop short of explicitly studying the role of financial pressures on job search behavior and its outcomes. They recommend further research could investigate, for instance, for which subgroups of the population this reduced job match quality matters more (Caliendo et al., 2013) or what the importance is of liquidity constraints in job search behavior (Tatsiramos and Van Ours, 2014). As Manroop and Richardson (2015, p.15) most recently put it: "What is needed is more in-depth understanding of the effects of financial hardship on job search intensity and quality and subsequent job search outcomes...”.

We answer these calls and study the impact of external financial pressures (proxied by the ability to pay recurring bills such as electricity, phone, gas, mortgage or rent) on unemployed job 
search behavior and its outcomes. We use Self-Determination Theory (SDT) ${ }^{1}$ as a theoretical framework to consolidate findings from the literature on unemployed job search and subsequent labor market outcomes, when job search takes place in an environment of financial pressures $-\mathrm{a}$ recognized research priority. SDT provides a unique theoretical framework, with which we can comprehensively understand the interplay between the type of job search motivation that is at work (motivation which in our case varies with financial pressure), concomitant job search and subsequent labor market outcomes. SDT leads us to three predictions. Financial pressure (1) spurs the unemployed to expand their job search activities - compared to the unemployed who search for employment in absence of financial pressure. However, SDT argues that only autonomous (or intrinsic) motivation contributes to outcome achievement; not external motivation, of which financial pressure is an example. The presence of financial pressure therefore shifts the overall composition of job search motivation away from autonomous job search motivation, a shift which SDT predicts reduces job search success. Hence even if financial pressure leads to job search activity expansion it need not enhance (2) the unemployed's chances to obtain a new job, (3) nor their likelihood to secure a better quality job (if they find a job) compared to the unemployed who search for employment in absence of financial pressure. SDT has been successfully applied in a similar context by Welters, Mitchell and Muysken (2014), who show that the quality of a job match depends on the type of motivation applied in line with SDT. They find that the presence of external job search motivation - on top of any other job search motivation - stimulates job search activity, does not improve the job find rate and if a job is found, even reduces the quality of that job in terms of reported job satisfaction. However, in their study, which focused on employed job search, external motivation arose from involuntary parttime work or casual labor contracts; not from external financial pressures.

1. For an extensive overview of SDT see Deci and Ryan (2000). 
To conduct our analysis, we exploit the Household, Income and Labour Dynamics in Australia (HILDA) data set. The HILDA data set is longitudinal in nature (14 waves are available) and includes information about the labor market status of respondents, job search behavior, financial pressures that respondents experience and - since we use several waves transition rates to different labor market positions in subsequent years. Crucially, to empirically test the validity of SDT among the unemployed, we must isolate the effect of financial pressure from other variables that might be at play simultaneously. We employ propensity score matching techniques to do so.

\section{Self-Determination Theory and the labor market}

Self-Determination Theory (SDT) surmises that people accomplish psychological wellbeing through need fulfilment in the competence, relatedness and autonomy domains (Deci and Ryan, 2000). As a result, people set goals that - if achieved - lead to need fulfilment and associated increases in psychological well-being. Employment provides the opportunity to achieve need fulfilment in all three domains, hence could be a goal for those out of employment to achieve psychological well-being. Indeed, Ferreira, Reitzle, Lee, Freitas, Santos, Alcoforado and Vondracek (2015) demonstrate that gaining employment after unemployment contributes to psychological well-being.

Importantly, SDT maintains that the type of motivation applied to pursue a goal influences the likelihood of goal accomplishment. That is, SDT differentiates between autonomous and external (or controlled) motivation. SDT predicts that although both types of motivation lead to goal pursuit, crucially, only autonomous motivation leads to goal accomplishment. SDT has been empirically validated in various settings including education 
(Miserandino, 1996), health (Williams, McGregor, Sharp, Levesque, Kouides, Ryan and Deci, 2006), political awareness (Koestner, Losier, Vallerand and Carducci 1996) and environmental awareness (Seguin, Pelletier and Hunsley, 1998).

\section{Financial pressure and controlled job search motivation}

Applied to the plight of the unemployed in the labor market, financial pressure frustrates need fulfilment in the autonomy domain, which in turn adversely impacts psychological wellbeing of the unemployed. For example, Waters and Moore (2001) find that economic deprivation during a spell of unemployment contributes to depression. Creed and Klisch (2005) find that financial strain increases psychological distress of the unemployed directly, but also indirectly, i.e. the unemployed develop a more negative outlook of the future under financial strain, which in turn causes psychological stress. For an overview of the negative relationship between financial pressure and psychological health refer to McKee-Ryan, Song, Wanberg and Kinicki's (2005) meta-analytical study on the relationship between well-being and unemployment. The reduced need fulfilment in the autonomy domain as a result of financial pressure and subsequent lower psychological health, implies that job search motivation becomes more externally regulated or controlled (Vansteenkiste, Lens, De Witte, De Witte and Deci, 2004; Vansteenkiste and Van den Broeck, in press). Or as Klehe, Zikic, Van Vianen, Koen and Buyken (2012, p. 137) put it: “...job search in the face of an economic stressor is mainly concerned with evading or freeing oneself from an aversive and threatening situation." 


\section{Controlled job search motivation, job search intensity and job search outcomes}

The effect of controlled job search motivation on job search intensity is topic of an emerging body of literature that successfully applies SDT to the labor market. Koen, Klehe and Vianen (2015) demonstrate that the degree to which a mandatory training course was considered useful in their pursuit of employment (i.e. the degree to which the external regulator was internalized), increased the subsequent search intensity of the unemployed. Vansteenkiste, Lens, De Witte, De Witte and Deci (2004) and Vansteenkiste, Lens, Witte and Feather (2005) include both autonomous and controlled motivation as separate independent variables in a regression explaining job search intensity. Autonomous motivation leads to higher job search intensity; controlled motivation has a positive but not significant effect on job search intensity in their study - presumably due to its weaker volitional strength. Halvari, Vansteenkiste, Brørby and Karlsen (2013), studying employed job search, find positive effects of both autonomous and economic (a type of controlled) motivation on job search intensity. Finally, Welters et al. (2014) confirm a positive relationship between controlled motivation and job search intensity of employees. Consequently, in terms of SDT this evidence suggests that - all else equal - the unemployed who experience financial pressure adopt more intense job search strategies than the unemployed who search for employment in absence of this controlled motivator. This is in line with empirical findings in the psychological literature that relate (perceived) financial strain, financial need or financial hardship to job search intensity (e.g. Vinokur and Caplan, 1987; Ullah, 1990; Wanberg, Kanfer and Rotundo, 1999; Kanfer, Wanberg and Kantrowitz, 2001).

However, these studies stop short of testing how autonomous and - more relevant to our study - controlled motivation affect the outcomes of job search. If, as SDT claims, (job search) motivation is a multi-dimensional concept, then an increase in motivation need not necessarily 
translate into a better outcome. Or as Vansteenkiste and Van den Broeck (in press, p. 17) put it: "Specifically, more strongly motivated jobless people are assumed to more quickly find a (new) job, presumably because they put greater effort into their searching. Yet, based on SDT, we maintain it is important to move beyond merely considering unemployed individuals' intensity of motivation and to additionally consider the sort or type of motivation they display." That is, SDT predicts that if the composition of job search motivation becomes more externally oriented (for example as a result of financial pressure) the chance of goal achievement in terms of job search outcomes declines, offsetting the positive effect of controlled motivation on the job search outcome through increased job search intensity. To the best of our knowledge, Welters et al. (2014) is the only labor market study that used SDT to test the effect of changes in the composition of job search motivation on job search outcomes, albeit for employed job searchers. They find that an employee who experiences additional controlled job search motivation, i.e. whose job search motivation as a result is more oriented towards controlled motivation, is not more likely to find a new job and if a new job is found they are less satisfied with that job. That suggests that only autonomous motivation leads to career advancement.

\section{Non-SDT literature on job search outcomes}

A rich body of (non-SDT) literature in economics exists on the effects of unemployment insurance (UI) design - in terms of its generosity measured by for instance benefit level, benefit duration, sanctions or the amount of search time without activity requirements - on the job find rate and/or the job match quality (see Tatsiramos and van Ours, 2014 for a recent literature review on UI design and job find rates). For recent contributions on UI design and job quality, see Nekoei and Weber, 2015; Berg and Vikström, 2014; Schmieder, von Wachter and Bender, in 
press; Caliendo et al., 2013; Gaure et al., 2012; van Ours and Vodopivec, 2008; Lalive, 2007; Centeno and Novo, 2006; Centeno, 2004). Some of these studies find no significant UI generosity job quality relation (van Ours and Vodopivec, 2008; Lalive, 2007), whereas others find negative (Schmieder et al., in press; Petrongolo, 2009) or positive relations (Nekoei and Weber, 2015; Berg and Vikström, 2014; Caliendo et al., 2013, Arni, Lalive and van Ours, 2013; Gaure et al., 2012; Centeno and Novo, 2006; Centeno, 2004). The majority of these studies focus on wages and/or the duration of the new job to assess job quality.

The mixed picture emerging from these studies may be a result of the implicit assumptions, stemming from a neoclassical vision, that (1) UI generosity and financial pressure are correlated similarly across the unemployed, i.e. a sanction, lowering of replacement rate or shortening of duration affect all unemployed similarly. This relates to the assumption that there is no involuntary unemployment and hence that all unemployed can reduce their reservation wage and as such “can always 'price' themselves into a job.” (Howell and Azizoglu, 2011: p 226).

(2) Job search motivation is a unidimensional concept, i.e. all motivators that the unemployed job searcher may experience contribute similarly to job search behavior and outcomes. This relates to the assumption that "there are no non-pecuniary benefits to employment, and no social or psychological costs to joblessness (there is only leisure, not idleness)" (Howell and Azizoglu, 2011: p 227).

SDT contests the second assumption. We apply SDT, testing the relations between unemployed job search, subsequent labor market outcomes and the type of job search motivation that is applied. Motivation which in our case varies with financial pressure. Specifically, we test three hypotheses: 
Hypothesis 1. The unemployed who are subjected to financial pressure (a controlled motivator) search more intensively for employment than the unemployed who are not subjected to financial pressure, all else equal.

Standard economics predicts that an unemployed person will only intensify their job search if it produces a reward (in terms of an increased job find chance or a better quality job). SDT predicts that job search intensification as a result of controlled motivation need not produce that reward. Therefore we pose two more hypotheses.

Hypothesis 2. The unemployed who are subjected to financial pressure are not more likely to secure employment than those who - all else equal - search in absence of financial pressure, notwithstanding the former's more intense job search.

Hypothesis 3. The unemployed who are subjected to financial pressure are not more likely to secure better quality employment than those who - all else equal - search in absence of financial pressure, notwithstanding the former's more intense job search.

With our SDT approach and financial pressure as variable of interest, we challenge the neoclassical vision from a labor supply side perspective and favor what Howell and Azizoglu (2011) label the 'Keynesian-institutionalist' labor market vision, which acknowledges the existence of involuntary unemployment and the existence of non-monetary benefits and costs of (un)employment. ${ }^{2}$ Besides the study at hand, only a small number of recent studies have investigated 'non UI-design factors' that - through their impact on either labor demand or labor supply behavior - may play a role during the job search process and may affect the quality of the job found. Caliendo, Gielen and Mahlstedt (2015) investigate the influence of home-ownership

2. See Howell and Azizoglu (2011) for an elaborate comparison between neoclassical and KeynesianInstitutionalist views on unemployment benefits and work incentives. 
on job quality, hypothesizing a negative relationship as home-ownership spatially constrains the unemployed's job search (i.e. a purported change in labor supply behavior). Apart from a reduced willingness to move, home-ownership does not affect other aspects of job search behavior such as the number of search channels used or applications submitted. Importantly, they find that, one year after entering unemployment, home-owning unemployed have secured better quality jobs (in terms of job satisfaction and earnings) than their renting counterparts - contrary to expectation (Caliendo et al., 2015). Phillips (2014) also focuses on a factor that may modify labor supply behavior. Using data from a field experiment in Washington DC, he studies the effect of a transportation cost subsidy available to unemployed job seekers on their job search intensity, job find rate and labor market outcomes. He finds that those who receive the subsidy increase their search intensity compared to the control group, but effects on the duration of the unemployment spell and labor market outcomes are statistically weak or insignificant. Alternatively, Caliendo and Lee (2013) concentrate on a factor that may impact labor demand behavior. They study the effect of obesity on the transition from unemployment to employment in Germany and find that despite more intense job search, obese women obtain lower quality jobs in terms of wages than non-obese women. However, they cannot generalize this finding as their result for women does not extend to men.

Our study makes three contributions. It extends (1) the emerging body of work in psychology testing SDT among the unemployed by studying the effect of financial pressure (the external regulator) on job search outcomes next to job search intensity, and $(2+3)$ the body of work in economics on post-unemployment job quality by incorporating (2) the type of job search motivation of the unemployed and (3) explicit measures of financial pressures experienced by the unemployed. Implications for future research as well as public policy will be discussed. 


\section{Data and empirical framework}

We use information from all 14 currently available waves of the Household, Income and Labour Dynamics in Australia (HILDA) data, spanning 2001 to 2014. The HILDA survey started in 2001 and is funded by the Australian Government. Data are collected through a telephone interview using a personal and household questionnaire, supplemented by a self-completion questionnaire ${ }^{3}$. We use questions from all three questionnaires to construct our variables. Our independent variables on financial pressure stem from the self-completion questionnaire, our dependent variables and most covariates stem from the personal questionnaire and some of the covariates, such as household income and composition, stem from the household survey.

\section{Independent variables}

Our independent variable of interest is financial pressure. It was measured in all available waves by asking respondents if they had experienced any of the following events since the beginning of the year due to a shortage of money ${ }^{4}$ :

1. Could not pay electricity, gas or telephone bills on time

2. Asked for financial help from friends / family

3. Could not pay the mortgage or rent on time

4. Pawned or sold something

5. Went without meals

6. Was unable to heat home

7. Asked for help from welfare / community organizations

3. See Summerfield, Freidin, Hahn, Li, Macalalad, Mundy, Watson, Wilkins and Wooden (2014) for detailed information on the HILDA data.

4. In the 2010 survey this question incorrectly referred to January 2009 instead of January 2010, rendering the 2010 answers to this question unusable. Therefore, the HILDA data do not contain answers to this question for 2010. 
These items have been successfully used in various strands of literature such as psychiatry (e.g. Butterworth, Olesen and Leach, 2012; Kiely, Leach, Olesen and Butterworth, 2015) and economics (e.g. La Cava and Simon, 2005; Breunig and Cobb-Clark, 2006). Factor analyses have shown that these items load onto one factor and that a simple addition of the items adequately calculates financial pressure (Butterworth and Crosier, 2006; Butterworth et al., 2012). Our own factor analyses on these items for each of the years in our sample (2001-2014) provided positive results consistent with those of previous studies ${ }^{5}$. Therefore, our first measure of financial pressure is a $(0,1)$ indicator, whose value is 1 for each unemployed person who answers 'yes' to any of these items and 0 if all are answered in the negative. We label this variable 'Overall financial pressure'.

Following Bray (2001), Breunig and Cobb-Clark (2006) and Kiely et al. (2015), we construct two composite measures of financial pressure labeled 'Hardship' (items 4, 5, 6 and 7) and the less severe 'Cash flow problems' (items 1, 2 and 3) - acknowledging that "the line between these dimensions may be blurred" Kiely et al. (2015: p. 90). Both are (0,1) variables coded 1 if 'yes' is answered to any of the relevant items; 0 if all are answered in the negative. Table 1 summarizes the incidence of financial pressure in our estimation sample. Almost half of the unemployed in our sample have experienced overall financial pressure since the beginning of the year in which they were interviewed (interviews typically occur in October). Almost a third experienced hardship - the most severe form of financial pressure - which is also known as 'deprivation' (Kiely et al., 2015). The individual item 'asked for financial help from friends / family' was the most prevalent type of financial pressure, indicated by a third of the unemployed in our sample.

5. Our factor analyses based on a tetrachoric correlation matrix showed only 1 eigenvalue above 1 for each year and across all years no factor loading lower than 0.73 with the highest at 0.88 . Moreover, Cronbach's Alpha was at least 0.73 and up to 0.77 across years. 
Table 1. Incidence of financial pressure in our sample of unemployed $(n=5,536)$

\begin{tabular}{lcc}
\hline Variable & Frequency & Percent \\
\hline Financial pressure survey items & & \\
Could not pay electricity, gas or telephone bills on time & 1,586 & 28.7 \\
Asked for financial help from friends / family & 1,795 & 32.4 \\
Could not pay the mortgage or rent on time & 851 & 15.4 \\
Pawned or sold something & 951 & 17.2 \\
Went without meals & 773 & 14.0 \\
Was unable to heat home & 429 & 7.8 \\
Asked for help from welfare / community organizations & 880 & 15.9 \\
& & \\
Composite financial pressure measures & & \\
Experienced Overall financial pressure & 2,642 & 47.7 \\
Experienced Hardship & 1,703 & 30.8 \\
Experienced Cash flow problems & 2,368 & 42.8 \\
\hline
\end{tabular}

\section{Dependent variables}

\section{Job search intensity}

Our first dependent variable of interest is job search intensity. Respondents were asked whether they engaged in various forms of job search at any point in the four weeks prior to the interview. Following Dockery (2004), we focus on a selection of job search methods, namely:

- Written, phoned or applied in person to an employer for work

- Answered an advertisement for a job

- Checked factory noticeboards, or used the touchscreens at Centrelink offices ${ }^{6}$

- Been registered with Centrelink as a jobseeker

- Contacted friends / relatives

Information about the frequency of job search activity (e.g. how often did they answer an advertisement for a job in the four weeks prior to the interview) is not available; nor is information about the quality of job search activity. We treat each of these job search methods as

6. Centrelink is the Australian public labor exchange office. 
a separate $(0,1)$ job search variable. Table 2 shows that the financially pressured unemployed engage significantly more in all these job search methods than the unemployed without financial pressure. Having written, phoned or applied in person to an employer is the most used search method for both groups, with three-quarters of the unemployed in our sample having done this in the four weeks prior to the survey interview.

\section{Job find success}

Our next dependent variable is job find success. We are only able to construct this variable for respondents who have remained in the panel for (at least) two consecutive years ${ }^{7}$. We constructed a $(0,1)$ variable. Respondents who changed from unemployment in year ' $t$ ' to employment in year ' $t+1$ ' were assigned 1 ; respondents who were unemployed in both years were assigned 0 . Table 2 shows that the financially pressured unemployed (financial pressure measured at time ' $t$ ') are significantly less likely to be employed in ' $t+1$ ' compared to the unemployed without financial pressures.

\section{Job quality}

Our final and most important set of dependent variables concerns job quality. Naturally, our job quality measures are only observed for those respondents who made the transition from unemployment at ' $t$ ' to employment at ' $t+1$ '. We include two objective indicators of job quality: the hourly gross wage and the weekly number of hours worked in the main job. ${ }^{8}$ We also include three subjective variables indicating respondents' satisfaction with different aspects of the job:

7. Respondents who report unemployment in year ' $t$ ' and employment in year ' $t+1$ ', but who report zero income and / or zero hours worked in ' $t+1$ ' are left out of the analysis.

8. Nearly all respondents (95\%) who found employment after a spell of unemployment, work one job; the remainder work two or more jobs. We chose to concentrate on objective indicators of the main job to align with the subjective job quality indicators, which refer to the main job. Results for objective indicators of all jobs (not shown) are similar to those for the main job. 
satisfaction with pay and the number of hours they work. These were all measured on a 0-10 scale, where 10 meant most satisfied with the aspect. Finally, we include a variable that bridges objective and subjective elements of job quality. That is, we make use of a question that asked reemployed respondents whether they had looked for a new job in the four weeks prior to the interview at ' $t+1$ ', which we code ' 1 ' for yes and ' 0 ' for no. The indicator itself is objective, but the reasons for resuming job search within a year after finding a job is among others based on a subjective appraisal of the current job. We interpret it as a signal of low job quality if one resumes job search just after transitioning from unemployment to work. We label this variable 'intention to turnover'.

We complement the analysis of objective indicators with an analysis of subjective indicators of job quality attributes, because the latter provide more holistic information about what the previously unemployed themselves consider job quality, given their current set of both physical needs (e.g. being able to afford food and shelter) and psychological needs in terms of SDT that the job helps fulfilling. For example, using hourly wages as an (objective) indicator of quality, neglects the fact that many components of job quality are not captured by wages. For instance, the unemployed who transition into employment may not be able to find jobs that provide them with enough hours to attain satisfactory weekly earnings. One could end up comparing 'job A', which pays an hourly wage of 25 dollars and offers 30 hours of work per week, to 'job B', which pays an hourly wage of 50 dollars yet offers only 10 hours of work. Comparing only hourly wages would lead to the conclusion that 'job B' offers better quality. However, the opportunity to earn a total of 750 dollars per week in 'job A', instead of only 500 dollars per week in 'job B', may be of much more value to the unemployed, hence, 'job A' may provide this person the highest job quality. As Osterman (2013) points out, this argument can be made for various components of job quality and this problem can be circumvented by focusing 
on reported satisfaction with job attributes. The main drawback of using subjective indicators is that personal attitudes may influence the satisfaction score which are unrelated to the - objective - quality of the job.

Table 2 shows that the unemployed who reported financial pressure at ' $t$ ' and transited to employment in ' $t+1$ ', report no different wage but a higher number of hours worked than the unemployed who escaped unemployment in absence of financial pressure. Moreover, $31 \%$ of those who reported financial pressure at time ' $t$ ' and have transited to employment in ' $t+1$ ', have intention to turnover at ' $t+1$ ', against $25 \%$ of those without financial pressure at ' $t$ '. Furthermore, those who experienced financial pressure report significantly lower satisfaction with their job's pay and number of hours worked than the unemployed who did not experience financial pressure during unemployment. Looking at the difference between the different severities of financial pressure, we see that those who experienced hardship at ' $t$ ' report lower absolute job satisfaction levels and show a higher intention to turnover in ' $t+1$ ' than those who experienced cash flow problems. Finally, the gaps in satisfaction with pay, satisfaction with the number of hours worked and the intention to turnover grow larger and more significant when we consider those who experienced hardship against those who did not experience hardship - vis a vis those who did/did not experience cash flow problems. This suggests that perceived job quality and the subsequent intention to turnover following an unemployment spell are more severely affected by experiences of hardship than by experiences of cash flow problems, which underscores that hardship is the more severe form of financial pressure (Kiely et al., 2015). 
Table 2. Search, success and job quality outcomes variables by financial pressure

\begin{tabular}{|c|c|c|c|c|c|c|c|c|c|}
\hline \multirow[b]{2}{*}{ Variable } & \multicolumn{3}{|c|}{$\begin{array}{l}\text { Overall financial } \\
\text { pressure }\end{array}$} & \multicolumn{3}{|c|}{ Hardship } & \multicolumn{3}{|c|}{ Cash flow problems } \\
\hline & No & $\begin{array}{l}\mathrm{t}- \\
\text { test }\end{array}$ & Yes & No & $\begin{array}{l}\mathrm{t}- \\
\text { test }\end{array}$ & Yes & No & $\begin{array}{l}\mathrm{t}- \\
\text { test }\end{array}$ & Yes \\
\hline \multicolumn{10}{|l|}{ Search variables $(n=5.536)$} \\
\hline Written, phoned or applied in person & 0.75 & & 0.76 & 0.75 & & 0.75 & 0.74 & $* *$ & 0.76 \\
\hline Answered a job advertisement & 0.50 & $* * *$ & 0.58 & 0.52 & $* * *$ & 0.58 & 0.51 & $* * *$ & 0.59 \\
\hline Checked noticeboards / Centrelink & 0.18 & $* * *$ & 0.34 & 0.20 & $* * *$ & 0.38 & 0.18 & $* * *$ & 0.35 \\
\hline Been registered with Centrelink & 0.28 & $* * *$ & 0.51 & 0.31 & $* * *$ & 0.57 & 0.30 & $* * *$ & 0.51 \\
\hline Contacted friends/relatives & 0.15 & $* * *$ & 0.18 & 0.16 & $* *$ & 0.18 & 0.15 & $* * *$ & 0.18 \\
\hline Job find success $(n=3.126)$ & 0.69 & $* * *$ & 0.59 & 0.68 & $* * *$ & 0.56 & 0.68 & $* * *$ & 0.59 \\
\hline \multicolumn{10}{|l|}{ Job quality (Objective) ( $n=1.983)$} \\
\hline Wage (log hourly wage) & 2.82 & & 2.82 & 2.82 & & 2.82 & 2.82 & & 2.82 \\
\hline Number of hours worked & 26.9 & $* * *$ & 29.7 & 27.5 & $* * *$ & 29.7 & 27.1 & $* * *$ & 29.7 \\
\hline Intention to turnover & 0.25 & $* * *$ & 0.31 & 0.25 & $* * *$ & 0.35 & 0.26 & $* *$ & 0.31 \\
\hline \multicolumn{10}{|l|}{ Job quality (Subjective) } \\
\hline Satisfaction with pay & 6.82 & $* * *$ & 6.48 & 6.77 & $* * *$ & 6.40 & 6.75 & $*$ & 6.55 \\
\hline $\begin{array}{l}\text { Satisfaction with number of hours } \\
\text { worked }\end{array}$ & 6.95 & $* * *$ & 6.62 & 6.95 & $* * *$ & 6.39 & 6.92 & $* * *$ & 6.63 \\
\hline
\end{tabular}

\section{Covariates}

Table 3 gives an overview of our covariates by type of financial pressure. We have restricted our sample to those who report to be unemployed and looking for work, are between 15 and 65 years of age and for whom all the covariates are non-missing. This leaves us with a sample of 5,536 unemployed respondents. Compared to the unemployed who experienced no financial pressure, the unemployed who did experience financial pressure are more often in their thirties or forties, female, indigenous, single, relatively lower educated, and / or have been unemployed for longer. Furthermore, the unemployed who experience financial pressure are more often renting rather than owning a home, more often live outside the major metropolitan areas, in states experiencing higher unemployment rates $^{9}$ and / or, unsurprisingly, have a lower

9. We include the (state) unemployment rate not only to account for different labor market conditions across space but also across time (i.e. control for the business cycle). 
household income. These differences are more pronounced for the unemployed who experience hardship rather than cash flow problems - most notably household type, unemployment duration, home ownership and household income. This underscores once more that hardship is the more severe form of financial pressure and it also lends validity to making the distinction between these two constructs of financial pressure.

Table 3. Descriptives by financial pressure

\begin{tabular}{|c|c|c|c|c|c|c|c|c|c|}
\hline \multirow[b]{2}{*}{ Variable } & \multicolumn{3}{|c|}{$\begin{array}{c}\text { Overall financial } \\
\text { pressure }\end{array}$} & \multicolumn{3}{|c|}{ Hardship } & \multicolumn{3}{|c|}{ Cash flow problems } \\
\hline & No & t-test & Yes & No & t-test & Yes & No & t-test & Yes \\
\hline Number of observations & 2,894 & & 2,642 & 3,833 & & 1,703 & 3,168 & & 2,368 \\
\hline \multicolumn{10}{|c|}{ Personal and household characteristics } \\
\hline \multicolumn{10}{|l|}{ Age } \\
\hline $15-29$ & 0.58 & $* * *$ & 0.54 & 0.57 & $* * *$ & 0.53 & 0.57 & $* *$ & 0.54 \\
\hline $30-39$ & 0.12 & $* * *$ & 0.20 & 0.14 & $* * *$ & 0.20 & 0.12 & $* * *$ & 0.21 \\
\hline $40-49$ & 0.14 & $* *$ & 0.16 & 0.14 & & 0.15 & 0.13 & $* * *$ & 0.16 \\
\hline $50-64$ & 0.17 & $* * *$ & 0.10 & 0.15 & $* * *$ & 0.11 & 0.17 & $* * *$ & 0.09 \\
\hline Gender ( 1 if male) & 0.53 & $* *$ & 0.50 & 0.51 & & 0.53 & 0.54 & $* * *$ & 0.48 \\
\hline \multicolumn{10}{|l|}{ Indigenous } \\
\hline Non-Indigenous Australia born & 0.74 & & 0.75 & 0.75 & & 0.74 & 0.74 & $*$ & 0.76 \\
\hline Non-Indigenous born elsewhere & 0.21 & $* * *$ & 0.16 & 0.19 & $* * *$ & 0.16 & 0.21 & $* * *$ & 0.15 \\
\hline Indigenous & 0.05 & $* * *$ & 0.09 & 0.05 & $* * *$ & 0.10 & 0.05 & $* * *$ & 0.09 \\
\hline \multicolumn{10}{|l|}{ Household type } \\
\hline Couple with dep children & 0.23 & & 0.21 & 0.23 & $* *$ & 0.20 & 0.23 & & 0.21 \\
\hline Couple without dep children & 0.44 & $* * *$ & 0.29 & 0.42 & $* * *$ & 0.26 & 0.43 & $* * *$ & 0.29 \\
\hline Single with dep children & 0.11 & $* * *$ & 0.15 & 0.12 & $* * *$ & 0.15 & 0.12 & $* * *$ & 0.16 \\
\hline Single without dep children & 0.04 & & 0.05 & 0.04 & & 0.05 & 0.04 & & 0.04 \\
\hline Single with non-related adults & 0.10 & $* * *$ & 0.17 & 0.10 & $* * *$ & 0.20 & 0.11 & $* * *$ & 0.17 \\
\hline Single & 0.08 & $* * *$ & 0.13 & 0.08 & $* * *$ & 0.14 & 0.08 & $* * *$ & 0.13 \\
\hline \multicolumn{10}{|l|}{ Educational attainment } \\
\hline Year 12 or below & 0.66 & & 0.65 & 0.65 & & 0.65 & 0.65 & & 0.65 \\
\hline Certificate III or IV & 0.15 & $* * *$ & 0.21 & 0.16 & $* * *$ & 0.22 & 0.16 & $* * *$ & 0.21 \\
\hline Advanced diploma & 0.05 & & 0.05 & 0.05 & & 0.05 & 0.06 & & 0.05 \\
\hline Bachelor degree or higher & 0.14 & $* * *$ & 0.09 & 0.13 & $* * *$ & 0.07 & 0.13 & $* * *$ & 0.09 \\
\hline \multicolumn{10}{|c|}{ Labor market and financial background } \\
\hline $\begin{array}{l}\text { Time (months) currently in } \\
\text { unemployment } \\
\text { Home ownership }\end{array}$ & 7.8 & $* * *$ & 9.9 & 8.1 & $* * *$ & 10.5 & 8.0 & $* * *$ & 9.9 \\
\hline
\end{tabular}




\begin{tabular}{lccc|ccc|ccc} 
Own / currently paying off mortgage & 0.62 & $* * *$ & 0.32 & 0.56 & $* * *$ & 0.28 & 0.60 & $* * *$ & 0.30 \\
Renting (or pay board) & 0.35 & $* * *$ & 0.65 & 0.41 & $* * *$ & 0.69 & 0.37 & $* * *$ & 0.66 \\
Live here rent free / life tenure & 0.03 & & 0.04 & 0.03 & & 0.04 & 0.03 & $* *$ & 0.04 \\
Gross weekly household income & 1,796 & $* * *$ & 1,102 & 1,663 & $* * *$ & 1,018 & 1,746 & $* * *$ & 1,089 \\
\hline Regional and temporal variables & & & & & & & & & \\
\hline 1 if in major metropolitan area & 0.59 & $* * *$ & 0.51 & 0.57 & $* * *$ & 0.51 & 0.58 & $* * *$ & 0.51 \\
State unemployment rate & 5.53 & $* * *$ & 5.69 & 5.56 & $* * *$ & 5.71 & 5.54 & $* * *$ & 5.70 \\
\hline
\end{tabular}

$* * * \mathrm{p}<0.01, * * \mathrm{p}<0.05, * \mathrm{p}<0.1$ on two-sided t-tests.

\section{Estimation results}

We follow Caliendo and Lee (2013) and Caliendo et al. (2015) and apply propensity score matching to estimate the effect of an independent variable of interest - in our case financial pressure - on job search, job find success and job quality. The first step consists of estimating the probability to experience financial pressure. We have done this separately for our three measures of financial pressure using logit. The results in Table 4 paint the same picture as the descriptives in Table 3. Unemployed females, those in their thirties or forties, singles, relatively lower educated and home renters are more likely to experience either overall financial pressure, hardship, cash flow problems or multiple of these. Conversely, the unemployed over fifty, migrants, couples without dependent children and home owners are less likely to experience financial pressures. In addition, the higher educated are less likely to experience hardship. These results demonstrate that the unemployed's experience of financial pressure depends on a range of circumstances. 
Table 4. Propensity score estimates

\begin{tabular}{|c|c|c|c|c|c|c|}
\hline \multirow[b]{2}{*}{ Variable } & \multicolumn{2}{|c|}{ Overall financial pressure } & \multicolumn{2}{|c|}{ Hardship } & \multicolumn{2}{|c|}{ Cash flow problems } \\
\hline & Coefficients & $\mathrm{Se}$ & Coefficients & $\mathrm{Se}$ & Coefficients & $\mathrm{Se}$ \\
\hline \multicolumn{7}{|l|}{ Personal and household characteristics } \\
\hline \multicolumn{7}{|l|}{ Age } \\
\hline $15-29$ & \multicolumn{6}{|c|}{ reference } \\
\hline $30-39$ & $0.620 * * *$ & $(0.087)$ & $0.482 * * *$ & $(0.088)$ & $0.574 * * *$ & $(0.086)$ \\
\hline $40-49$ & $0.281 * * *$ & $(0.089)$ & $0.175^{*}$ & $(0.094)$ & $0.323 * * *$ & $(0.089)$ \\
\hline $50-64$ & $-0.318^{* * *}$ & $(0.101)$ & -0.069 & $(0.110)$ & $-0.390 * * *$ & $(0.105)$ \\
\hline Gender ( 1 if male) & $-0.162 * * *$ & $(0.060)$ & 0.046 & $(0.063)$ & $-0.297 * * *$ & $(0.060)$ \\
\hline \multicolumn{7}{|l|}{ Indigenous } \\
\hline Non-Indigenous Australia born & \multicolumn{6}{|c|}{ reference } \\
\hline Non-Indigenous born elsewhere & $-0.324 * * *$ & $(0.082)$ & $-0.193 * *$ & $(0.089)$ & $-0.427 * * *$ & $(0.084)$ \\
\hline Indigenous & 0.014 & $(0.119)$ & $0.202^{*}$ & $(0.116)$ & -0.052 & $(0.116)$ \\
\hline \multicolumn{7}{|l|}{ Household type } \\
\hline Couple with dep children & \multicolumn{6}{|c|}{ reference } \\
\hline Couple without dep children & $-0.304 * * *$ & $(0.082)$ & $-0.272 * * *$ & $(0.090)$ & $-0.302 * * *$ & $(0.083)$ \\
\hline Single with dep children & -0.163 & $(0.104)$ & -0.087 & $(0.108)$ & $-0.224 * *$ & $(0.104)$ \\
\hline Single with non dep children & 0.054 & $(0.152)$ & 0.108 & $(0.159)$ & -0.053 & $(0.154)$ \\
\hline Single with related or non-related adults & 0.050 & $(0.106)$ & $0.250 * *$ & $(0.107)$ & -0.090 & $(0.105)$ \\
\hline Single & $0.410 * * *$ & $(0.113)$ & $0.514 * * *$ & $(0.115)$ & $0.370 * * *$ & $(0.113)$ \\
\hline \multicolumn{7}{|l|}{ Educational attainment } \\
\hline Year 12 or below & \multicolumn{6}{|c|}{ reference } \\
\hline Certificate III or IV & $0.258 * * *$ & $(0.080)$ & $0.250 * * *$ & $(0.081)$ & $0.212 * * *$ & $(0.079)$ \\
\hline Advanced diploma & 0.152 & $(0.135)$ & 0.121 & $(0.145)$ & 0.054 & $(0.138)$ \\
\hline Bachelor degree or higher & -0.154 & $(0.105)$ & $-0.387 * * *$ & $(0.120)$ & -0.139 & $(0.107)$ \\
\hline \multicolumn{7}{|l|}{ Labor market and financial background } \\
\hline Time (months) currently in unemployment & 0.002 & $(0.002)$ & 0.002 & $(0.002)$ & 0.002 & $(0.002)$ \\
\hline \multicolumn{7}{|l|}{ Home ownership } \\
\hline Own / currently paying off mortgage & \multicolumn{6}{|c|}{ reference } \\
\hline Renting (or pay board) & $0.951 * * *$ & $(0.066)$ & $0.859 * * *$ & $(0.072)$ & $0.984 * * *$ & $(0.067)$ \\
\hline Live here rent free / life tenure & $0.481 * * *$ & $(0.161)$ & $0.413 * *$ & $(0.171)$ & $0.627 * * *$ & $(0.161)$ \\
\hline Gross weekly household income & $-0.000 * * *$ & $(0.000)$ & $-0.000 * * *$ & $(0.000)$ & $-0.000 * * *$ & $(0.000)$ \\
\hline \multicolumn{7}{|l|}{ Regional and temporal variables } \\
\hline 1 if in major metropolitan area & $-0.115^{*}$ & $(0.062)$ & -0.057 & $(0.065)$ & $-0.110 *$ & $(0.062)$ \\
\hline State unemployment rate & $0.134 * * *$ & $(0.030)$ & $0.115^{* * *}$ & $(0.032)$ & $0.132 * * *$ & $(0.030)$ \\
\hline Constant & $-0.764 * * *$ & $(0.204)$ & $-1.622 * * *$ & $(0.218)$ & $-0.849 * * *$ & $(0.206)$ \\
\hline Observations & \multicolumn{2}{|c|}{5,536} & \multicolumn{2}{|c|}{5,536} & \multicolumn{2}{|c|}{5,536} \\
\hline Pseudo r-squared & \multicolumn{2}{|c|}{0.1194} & \multicolumn{2}{|c|}{0.1042} & \multicolumn{2}{|c|}{0.1188} \\
\hline Log likelihood & \multicolumn{2}{|c|}{-3374.1294} & \multicolumn{2}{|c|}{-3060.6313} & \multicolumn{2}{|c|}{-3330.1104} \\
\hline
\end{tabular}

Standard errors in parentheses. ${ }^{* * *} \mathrm{p}<0.01,{ }^{*} \mathrm{p}<0.05,{ }^{*} \mathrm{p}<0.1$ 
Figure 1 shows the propensity score distribution. Although there is substantial overlap and thus a wide region of common support, there are some differences in the tails. To err on the side of caution we imposed common support to obtain the matching results we present in Table 5. Furthermore, we applied the Epanechnikov kernel and a bandwidth of 0.06. In testing the sensitivity of the results we follow Caliendo and Kopeinig (2008) and put emphasis on trying different bandwidths (0.02 and 0.2). In addition, we tested imposing common support using a trimming of 5\% and using a nearest neighbor kernel instead of the Epanechnikov kernel. Our results proved robust across all different varieties.

Figure 1. Propensity score distribution

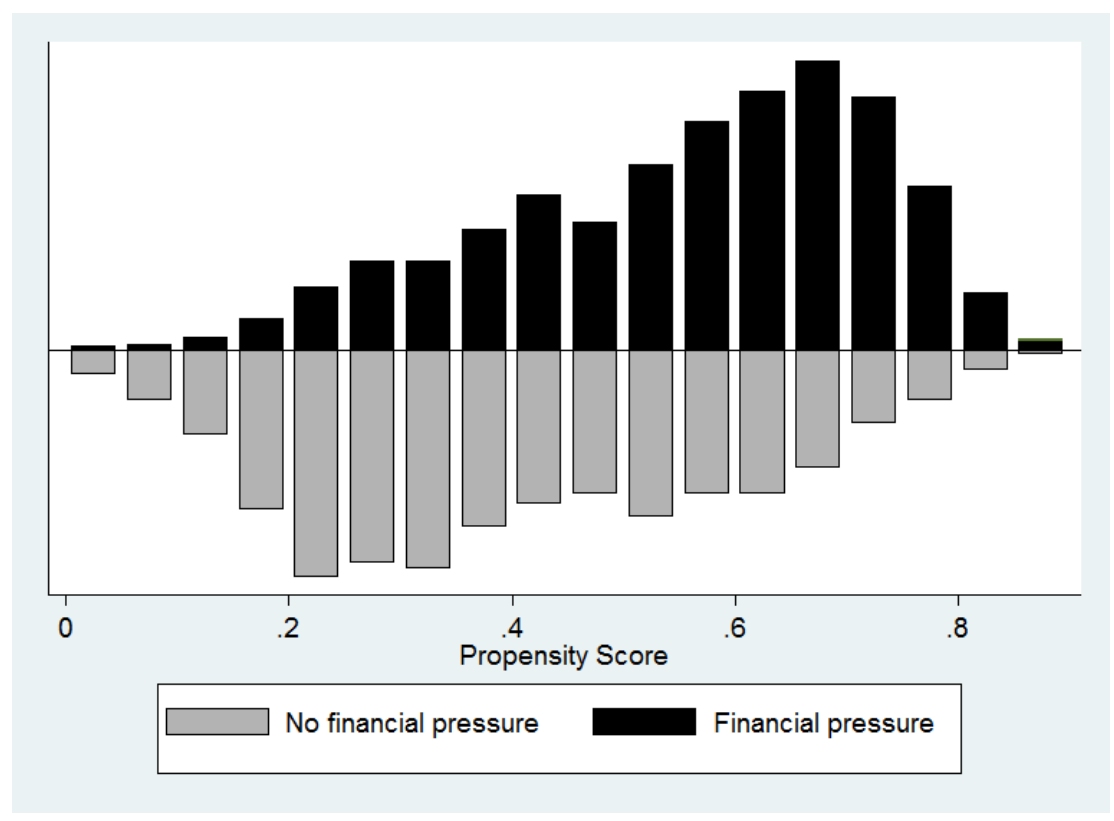

The results confirm our first hypothesis that financial pressure increases search intensity. We find that the unemployed with financial pressure, whether this is overall financial pressure, hardship or cash flow problems, make more use of all search channels ${ }^{10}$. We also confirm our second hypothesis. That is, even though the unemployed who experience financial pressure exhibit more

10. The only combination of search channel and type of financial pressure for which we do not find a statistically significant effect is 'having written, phoned or applied in person' and hardship. 
intense job search behavior, they are not more likely to find a job and in the case of hardship even less likely to find a job than the unemployed searching without financial pressure. Further, we confirm hypothesis 3 for both objective and subjective indicators. Financial pressure does not impact on the objective quality of the job (both in terms of hourly wages and number of hours worked) if the unemployed is successful at finding a job. This is none withstanding the fact that the financially pressurized unemployed search more intensively. The unemployed experiencing hardship (which also translates into financial pressure overall) are more likely to resume job search within a year of finding the current job than those without hardship. This suggests that the financially pressurized unemployed are less satisfied with their new job - again suggesting that intensified job search as a result of hardship does not produce better rather worse (subjective) outcomes. This pattern also emerges from the analysis of subjective indicators. The unemployed experiencing hardship (which again translates into financial pressure overall) are less satisfied with pay and hours worked in their new job than the unemployed who found a job without hardship ${ }^{11}$.

11. We also tested the effect of financial pressure on three additional constructs of job quality, together labeled as 'psychosocial job quality': (1) job demand and job complexity (2) job control (3) job security. For a detailed report on the development, cohesion and validity of these constructs, see Leach, Butterworth, Rodgers and Strazdins (2010). Job demand and job complexity consists of items referring to the content of the job such as 'My job is more stressful than I had ever imagined', 'My job is complex and difficult' and 'I use my skills in current job'. Job control consists of items referring to the employee's autonomy such as 'I have freedom to decide how I do my own work'. Job security is more self-explanatory and sample items are 'I have a secure future in my job' and 'Company I work for will still be in business in 5 years'. As these variables are only available for a subsample of 1,672 respondents, instead of the 1,983 respondents for which we estimated both our objective and subjective job quality indicators, we do not report these additional analyses in Table 5. Results of these additional analyses show no effect of financial pressure overall, hardship or cash-flow problems on (1) job demand and job complexity and (2) job control. Thus the financially pressurized unemployed do not find better quality jobs in terms of the job's complexity, skills utilization and autonomy, none withstanding their more intense job search. This underscores the result from our main analyses that there is no significant effect of financial pressure on wages and hours worked, which one may expect would otherwise have been reflected in differences in job demands and job complexity and/or job control. The only significant result from our additional analyses occurs for the third construct; job security. We find a significantly ( $\mathrm{p}=0.023$ ) negative effect of hardship on this measure of perceived job security. This underscores our main analyses result that, although both groups of unemployed end up in jobs that are equal in content, autonomy, wages and hours, the conditions surrounding the job are perceived more negatively by the unemployed who experienced financial pressure. 
Table 5. Matching estimates

\begin{tabular}{|c|c|c|c|c|c|c|c|}
\hline & Effect & $\mathrm{Se}$ & $n$-treated & $n$-untreated & Off & MnBias & MdBias \\
\hline \multicolumn{8}{|l|}{ A. Financial pressure overall } \\
\hline \multicolumn{8}{|l|}{ Search variables } \\
\hline Written, phoned or applied in person & $0.032 * *$ & 0.014 & 2,639 & 2,894 & 3 & 1.6 & 1.6 \\
\hline Answered a job advertisement & $0.083^{* * *}$ & 0.015 & $"$ & $"$ & $"$ & $"$ & $"$ \\
\hline Checked noticeboards / Centrelink & $0.097 * * *$ & 0.015 & $"$ & $"$ & $"$ & $"$ & $"$ \\
\hline Been registered with Centrelink & $0.116^{* * *}$ & 0.015 & $"$ & $"$ & $"$ & $"$ & $"$ \\
\hline Contacted friends/relatives & $0.039 * * *$ & 0.012 & $"$ & $"$ & $"$ & $"$ & $"$ \\
\hline Job find success & -0.016 & 0.021 & 1,458 & 1,663 & 5 & 1.7 & 1.8 \\
\hline \multicolumn{8}{|l|}{ Job quality variables (Objective) } \\
\hline Wage (log hourly wage) & 0.006 & 0.026 & 850 & 1,133 & 0 & 2.1 & 1.9 \\
\hline Number of hours worked & 0.605 & 0.826 & $"$ & $"$ & $"$ & $"$ & $"$ \\
\hline Intention to turnover & $0.051 * *$ & 0.025 & $"$ & $"$ & $"$ & $"$ & $"$ \\
\hline \multicolumn{8}{|l|}{ Job quality variables (Subjective) } \\
\hline Satisfaction with pay & $-0.315^{* * *}$ & 0.121 & $"$ & $"$ & $"$ & $"$ & $"$ \\
\hline Satisfaction with hours worked & $-0.242 *$ & 0.136 & $"$ & $"$ & $"$ & $"$ & $"$ \\
\hline \multicolumn{8}{|l|}{ B. Hardship } \\
\hline \multicolumn{8}{|l|}{ Search variables } \\
\hline Written, phoned or applied in person & 0.013 & 0.013 & 1,702 & 3,833 & 1 & 1.0 & 0.9 \\
\hline Answered a job advertisement & $0.065^{* * *}$ & 0.016 & $"$ & $"$ & $"$ & $"$ & $"$ \\
\hline Checked noticeboards / Centrelink & $0.100 * * *$ & 0.014 & $"$ & $"$ & $"$ & $"$ & $"$ \\
\hline Been registered with Centrelink & $0.142 * * *$ & 0.016 & $"$ & $"$ & $"$ & $"$ & $"$ \\
\hline Contacted friends/relatives & $0.033^{* * *}$ & 0.012 & $"$ & $"$ & $"$ & $"$ & " \\
\hline Job find success & $-0.038^{*}$ & 0.021 & 925 & 2,200 & 1 & 1.1 & 0.8 \\
\hline \multicolumn{8}{|l|}{ Job quality variables (Objective) } \\
\hline Wage (log hourly wage) & 0.021 & 0.030 & 511 & 1,472 & 0 & 1.8 & 1.7 \\
\hline Number of hours worked & 0.082 & 0.840 & $"$ & $"$ & $"$ & $"$ & $"$ \\
\hline Intention to turnover & $0.104 * * *$ & 0.027 & $"$ & $"$ & $"$ & $"$ & $"$ \\
\hline \multicolumn{8}{|l|}{ Job quality variables (Subjective) } \\
\hline Satisfaction with pay & $-0.314 * *$ & 0.154 & $"$ & $"$ & $"$ & $"$ & $"$ \\
\hline Satisfaction with hours worked & $-0.507 * * *$ & 0.146 & $"$ & $"$ & $"$ & $"$ & $"$ \\
\hline \multicolumn{8}{|l|}{ C. Cash flow } \\
\hline \multicolumn{8}{|l|}{ Search variables } \\
\hline Written, phoned or applied in person & $0.047 * * *$ & 0.015 & 2,366 & 3,168 & 2 & 1.4 & 1.3 \\
\hline Answered a job advertisement & $0.078 * * *$ & 0.016 & $"$ & $"$ & $"$ & $"$ & $"$ \\
\hline Checked noticeboards / Centrelink & $0.108 * * *$ & 0.014 & $"$ & $"$ & $"$ & $"$ & $"$ \\
\hline Been registered with Centrelink & $0.109^{* * *}$ & 0.015 & $"$ & $"$ & $"$ & $"$ & $"$ \\
\hline Contacted friends/relatives & $0.046^{* * *}$ & 0.010 & $"$ & $"$ & $"$ & $"$ & $"$ \\
\hline Job find success & -0.012 & 0.018 & 1,311 & 1,811 & 4 & 1.6 & 1.4 \\
\hline
\end{tabular}


Job quality variables (Objective)

Wage (log hourly wage)

$\begin{array}{lll}0.015 & 0.027 & 767\end{array}$

1,216

2.3

Number of hours worked

$0.720 \quad 0.809$

Intention to turnover

$0.042 \quad 0.027$

Job quality variables (Subjective)

Satisfaction with pay

$-0.198$

0.129

Satisfaction with hours worked

$-0.223^{*}$

0.126

$* * * p<0.01, * * p<0.05, * p<0.1$

Results are based on Epanechnikov kernel matching with common support and a bandwidth of 0.06. Off is the number of observations outside the common support area. MnBias and MdBias are the mean and median standardized bias after estimating. These are all well below the 3\% that is considered sufficient (Caliendo and Kopeinig, 2008). Standard errors were calculated using 250 bootstrap replications.

Interestingly, the propensity score matching analysis demonstrates that the unemployed experiencing hardship are less satisfied about the job that they find (both in terms of pay and hours worked) than the unemployed who find a job without hardship, even though objectively (hourly wages and hours worked) there is no difference between the jobs of the two groups. We hypothesize two reasons which may explain this finding. First, those experiencing financial pressure require additional income (to service debts) as opposed to those without financial pressure, which may explain why the former are less satisfied with objectively similar jobs. Second, financial pressure may impact personal attitudes. Perhaps financial pressure causes a more general negative outlook on life, which may cause a more negative appraisal of the job. We tested the relevance of both reasons by regressing subjective indicators of job quality (satisfaction with pay and hours worked respectively) of the job in period ' $t+1$ ' on (1) the relevant objective indicator of job quality (hourly wage and hours worked respectively); (2) a dummy variable indicating overall financial pressure, hardship or cash flow in period ' $t$ '; (3) a variable measuring the attitude of the respondent ${ }^{12}$; and (4) a set of control variables as in Table 4.

12. Respondents were asked whether they had been a happy person in the last four weeks - ranging from 'none of the time' to 'all of the time'. 
Table 6 contains the results of this set of regressions, which confirms a strong relationship between objective and subjective measures. More importantly, it also shows the importance of attitudes in general and underscores the independent impact of financial pressure (for financial pressure overall and hardship). These findings can reconcile the difference in subjective job appraisal for objectively similar jobs.

Table 6. Ordered probit estimates of subjective job quality

\begin{tabular}{|c|c|c|c|c|c|c|}
\hline \multirow{2}{*}{ Dependent variables } & \multicolumn{2}{|c|}{$\begin{array}{c}\text { A. Financial pressure overall } \\
\text { Satisfaction with: }\end{array}$} & \multicolumn{2}{|c|}{ B. Hardship } & \multicolumn{2}{|c|}{ C. Cash flow } \\
\hline & $\begin{array}{l}\text { Satisf } \\
\text { Pay }\end{array}$ & $\begin{array}{l}\text { with: } \\
\text { Hours } \\
\text { worked }\end{array}$ & $\begin{array}{l}\text { Satisf } \\
\text { Pay }\end{array}$ & $\begin{array}{l}\text { on with: } \\
\text { Hours } \\
\text { worked }\end{array}$ & $\begin{array}{l}\text { Satisf } \\
\text { Pay }\end{array}$ & $\begin{array}{l}\text { n with: } \\
\text { Hours } \\
\text { worked }\end{array}$ \\
\hline Objective pay & $0.013 * * *$ & & $0.013 * * *$ & & $0.013 * * *$ & \\
\hline Objective hours worked & & $0.011 * * *$ & & $0.010 * * *$ & & $0.011 * * *$ \\
\hline Financial pressure & $-0.119 * *$ & $-0.105 * *$ & $-0.110 *$ & $-0.172 * * *$ & -0.053 & $-0.091 *$ \\
\hline Optimistic attitude: & & & & & & \\
\hline - None of the time & reference & reference & reference & reference & reference & reference \\
\hline - A little of the time & 0.38 & 0.20 & 0.37 & 0.17 & $0.39 *$ & 0.21 \\
\hline - Some of the time & $0.42 *$ & 0.20 & $0.41 *$ & 0.17 & $0.43 * *$ & 0.21 \\
\hline - A good bit of the time & $0.45 * *$ & 031 & $0.44 * *$ & 0.28 & $0.47 * *$ & 0.33 \\
\hline - Most of the time & $0.53 * *$ & $0.38 *$ & $0.52 * *$ & $0.34 *$ & $0.55^{* *}$ & $0.39 * *$ \\
\hline - All of the time & $0.65 * * *$ & $0.70 * * *$ & $0.64 * * *$ & $0.66^{* * *}$ & $0.68 * * *$ & $0.71 * * *$ \\
\hline Log pseudolikelihood & $-4,164$ & $-4,229$ & $-4,165$ & $-4,227$ & $-4,166$ & $-4,230$ \\
\hline $\mathrm{N}$ & 1,978 & 1,978 & 1,978 & 1,978 & 1,978 & 1,978 \\
\hline
\end{tabular}

$* * * \mathrm{p}<0.01, * * \mathrm{p}<0.05, * \mathrm{p}<0.1 . \dagger$ Regressions included all control variables listed in Table 4 (not shown).

\section{Discussion}

Standard economic theory suggests that the application (or threat) of benefit sanctions (which intend to exert financial pressure on the unemployed) is an effective measure to provide financial incentives to the unemployed to search for employment. Its effectiveness has been tested extensively. Abbring et al. (2005), Van den Berg, Van der Klaauw and Van Ours (2004) and Van der Klaauw and Van Ours (2013) for the Netherlands, Lalive, Ours and Zweimüller (2005) for 
Switzerland, Svarer (2011) for Denmark and Boockmann, Thomsen and Walter (2009) for Germany confirm a positive association between the application of benefit sanctions and the job find rate. These studies conjecture that financial pressure increases search intensity. Rather than using a benefit sanction, we used direct measures of financial pressure in our analysis. A benefit sanction is, after all, only one of countless potential contributors to financial pressure; as we show in Table 4 the unemployed's experience of financial pressure depends on a range of circumstances. Consequently, assuming that a benefit sanction will financially pressurize all unemployed in similar ways is contestable. Depending on the presence of potential other contributors, benefit sanctions may or may not cause financial pressure. Our analysis, grounded in SDT, helps to confirm the conjecture arising from the benefit sanction literature. That is, an increase in financial pressure serves as a controlled (external) motivator, which indeed spurs job search intensity (our first hypothesis).

However, because it is a controlled motivator, SDT predicts that financial pressure leads to more externally oriented job search motivation, which reduces the rate of job search success, offsetting the positive effect of intensified job search. We confirm both hypotheses related to this argument. The financially pressurized unemployed are not more likely to find a job nor a better quality job - none withstanding their higher job search intensity. Since financial pressure increases job search intensity, it seems justified to explore reasons for the ineffectiveness of the additional job search in the job search domain. The unemployed whose search motivation is more controlled rather than autonomous may engage in more haphazard rather than focused job search strategies (Crossley and Highhouse, 2005) or in search in which they take less personal initiative (Grant, Nurmohamed, Ashford and Dekas, 2011). Also, Koen, Klehe, Van Vianen, Zikic and Nauta (2010) find a link between the presence of external pressure and the effectiveness of job search strategies to achieve high quality job matches, i.e. if external pressure to find a job is 
exerted, the use of an exploratory job search strategy is ineffective. Vinokur and Schul (2002) who, as we do, find that financial strain indeed facilitates finding a job by increasing the job search intensity but at the same time hinders it by increasing depressive symptoms.

SDT may also explain why Caliendo et al. (2015) find - contrary to their expectation - that the unemployed who are home owners find better quality jobs (in terms of job satisfaction and earnings) than their home renting counterparts. They hypothesized that home ownership would spatially constrain the unemployed, leading to worse employment outcomes. However, if home ownership is an indicator of (relative) financial security (results in our Table 4 show that home owning unemployed are relatively less likely to experience financial pressure), the search process might be more autonomously oriented, which explains better outcomes.

The main findings from this article, that financial pressure on the unemployed indeed leads to increased search activity, yet not to better quality jobs, are important in the context of benefit sanctions, as (threats of) these sanctions arguably intend to financially pressurize the unemployed. If the goal of benefit sanctions is to increase search activity per se, benefit sanctions are effective. However, if the goal of benefit sanctions goes beyond increased search activity and also includes job quality, our findings confirm the findings of other studies that benefit sanctions are ineffective (Nekoei and Weber, 2015; Berg and Vikström, 2014; Arni et al., 2013; Petrolongo, 2009). The innovation of our research is that we (a) use direct measures of financial pressure rather than indirect measures (like a benefit sanction) to demonstrate the link between financial pressure and search intensity and its outcome and (b) use a theoretical framework embedded in psychology that can explain why increased search intensity need not necessarily lead to improved outcomes.

Furthermore, this study confirms that financial pressure should be added to the array of determinants of job quality following a spell of unemployment, which others have hypothesized 
(Tatsiramos and Van Ours, 2014; Manroop and Richardson, 2015). We also confirm that hardship, rather than cash flow problems, is the more severe type of financial pressure.

Also, this study shows that one should be careful using subjective indicators of job quality. We find strong supporting evidence suggesting that financial pressure may increase the expectations (in terms of pay and hours worked) of future jobs and impact attitudes to life, which may explain why quality of objectively identical jobs is perceived differently.

Finally, it should be noted that our research focuses on the immediate outcome of the job search process; not longer-run outcomes. It is possible that the financially pressurized unemployed who found a job catch up over time with the non-pressurized in terms of job quality, although SDT would not predict this and findings by Welters et al. (2014) do not support this.

\section{Conclusions}

This study used Australian longitudinal data to demonstrate that financial pressure (or its components hardship and cash flow problems) induces the unemployed to intensify their job search. However, increased job search intensity as a result of financial pressure does not improve the job find rate nor the quality of the job in terms of pay or hours worked in the event employment is secured. Moreover, even though the financially pressurized unemployed do not suffer an objective job quality penalty in terms of wages or hours worked, they do suffer from a subjective job quality penalty as they are less satisfied with their wage and number of hours worked if a job is secured and exhibit a higher intention to turnover than otherwise identical unemployed without financial pressure. To sum up, the financially pressurized unemployed, who in so far as the data allow are similar in relevant aspects to the unemployed we use as a benchmark, are less well-off psychologically. 
These findings are predicted by Self-Determination Theory, which argues that financial pressure is a controlled motivator to search for work. Controlled motivators are effective in terms of producing job search activity, but ineffective in attaining better labor market outcomes in terms of job search success or job quality.

If the design of labor market policies relies on controlled motivation to enact behavioral change on the part of the unemployed, policymakers should be aware of the limitations of what that behavioral change can achieve. 


\section{References}

Abbring, J. H., Berg, G. J., \& Ours, J. C. (2005). The effect of unemployment insurance sanctions on the transition rate from unemployment to employment*. The Economic Journal, $115(505), 602-630$.

Arni, P., Lalive, R., \& Van Ours, J. C. (2013). How effective are unemployment benefit sanctions? Looking beyond unemployment exit. Journal of applied econometrics, 28(7), $1153-1178$.

Berg, G. J., \& Vikström, J. (2014). Monitoring job offer decisions, punishments, exit to work, and job quality. The Scandinavian journal of economics, 116(2), 284-334.

Bloemen, H. G., \& Stancanelli, E. G. (2001). Individual wealth, reservation wages, and transitions into employment. Journal of Labor Economics, 19(2), 400-439.

Boockmann, B., Thomsen, S. L., \& Walter, T. (2009). Intensifying the Use of Benefit Sanctions: An Effective Tool to Shorten Welfare Receipt and Speed Up Transitions to Employment? IZA DP 4580

Bray, J. R. (2001). Hardship in Australia: an analysis of financial stress indicators in the 199899 Australian Bureau of Statistics Household Expenditure Survey. FaHCSIA Occasional Paper, (4). Department of Family and Community Services, Canberra.

Breunig, R., \& Cobb-Clark, D. (2006). Understanding the factors associated with financial stress in Australian households. Australian Social Policy. 2005, 13-64.

Butterworth, P., \& Crosier, T. (2006). Deriving a measure of financial hardship from the HILDA survey. Australian Social Policy. 2005, 1-12.

Butterworth, P., Olesen, S. C., \& Leach, L. S. (2012). The role of hardship in the association between socio-economic position and depression. Australian and New Zealand Journal of 
Psychiatry, 46(4), 364-373.

Caliendo, M., Gielen, A. C., \& Mahlstedt, R. (2015). Home-Ownership, Unemployed's Job Search Behavior and Post-Unemployment Outcomes. Economics Letters 137, 218-221.

Caliendo, M., \& Kopeinig, S. (2008). Some practical guidance for the implementation of propensity score matching. Journal of economic surveys, 22(1), 31-72.

Caliendo, M., \& Lee, W. S. (2013). Fat chance! Obesity and the transition from unemployment to employment. Economics \& Human Biology, 11(2), 121-133.

Caliendo, M., Tatsiramos, K., \& Uhlendorff, A. (2013). Benefit Duration, Unemployment Duration and Job Match Quality: A Regression-Discontinuity Approach. Journal of Applied Econometrics, 28(4), 604-627.

Centeno, M. (2004). The match quality gains from unemployment insurance. Journal of Human resources, 39(3), 839-863.

Centeno, M., \& Novo, Á. A. (2006). The impact of unemployment insurance on the job match quality: a quantile regression approach. Empirical Economics, 31(4), 905-919.

Chetty, R. (2008). Moral Hazard versus Liquidity and Optimal Unemployment Insurance. Journal of Political Economy, 116(2), 173-234.

Creed, P. A., \& Klisch, J. (2005). Future outlook and financial strain: testing the personal agency and latent deprivation models of unemployment and well-being. Journal of occupational health psychology, 10(3), 251.

Crossley, C. D., \& Highhouse, S. (2005). Relation of job search and choice process with subsequent satisfaction. Journal of Economic Psychology, 26(2), 255-268.

Deci, E. L., \& Ryan, R. M. (2000). The" what" and" why" of goal pursuits: Human needs and the self-determination of behavior. Psychological inquiry, 11(4), 227-268.

Dockery, A. M. (2004). Looking inside the unemployment spell. Australian Journal of Labour 
Economics, 7(2), 175.

Ferreira, J. A., Reitzle, M., Lee, B., Freitas, R. A., Santos, E. R., Alcoforado, L., \& Vondracek, F. W. (2015). Configurations of unemployment, reemployment, and psychological wellbeing: A longitudinal study of unemployed individuals in Portugal. Journal of Vocational Behavior, 91, 54-64.

Filges, T., Geerdsen, L. P., Knudsen, A. S. D., \& Jørgensen, A. M. K. (2015). Unemployment Benefit Exhaustion Incentive Effects on Job-Finding Rates. Research on Social Work Practice, 25(1), 21-43.

Gaure, S., Røed, K., \& Westlie, L. (2012). Job search incentives and job match quality. Labour Economics, 19(3), 438-450.

Grant, A. M., Nurmohamed, S., Ashford, S. J., \& Dekas, K. (2011). The performance implications of ambivalent initiative: The interplay of autonomous and controlled motivations. Organizational Behavior and Human Decision Processes, 116(2), 241-251.

Halvari, H., Vansteenkiste, M., Brørby, S., \& Karlsen, H. P. (2013). Examining antecedents and outcomes of part-time working nurses' motives to search and not to search for a full-time position. Journal of Applied Social Psychology, 43(8), 1608-1623.

Howell, D. R. \& Azizoglu, B. M. (2011). Unemployment benefits and work incentives: the US labour market in the Great Recession. Oxford Review of Economic Policy, 27, 221-240.

Kanfer, R., Wanberg, C. R., \& Kantrowitz, T. M. (2001). Job search and employment: A personality-motivational analysis and meta-analytic review. Journal of Applied psychology, 86(5), 837.

Kiely, K. M., Leach, L. S., Olesen, S. C., \& Butterworth, P. (2015). How financial hardship is associated with the onset of mental health problems over time. Social psychiatry and psychiatric epidemiology, 50(6), 909-918. 
Klehe, U. C., Zikic, J., Van Vianen, A. E. M., Koen, J., \& Buyken, M. (2012). Coping proactively with economic stress: Career adaptability in the face of job insecurity, job loss, unemployment, and underemployment. Research in Occupational Stress and Well Being, 10, 131-176.

Koen, J., Klehe, U. C., \& Vianen, A. E. (2015). Employability and Job Search after Compulsory Reemployment Courses: The Role of Choice, Usefulness, and Motivation. Applied Psychology, 64 (4), 674-700.

Koen, J., Klehe, U. C., Van Vianen, A. E., Zikic, J., \& Nauta, A. (2010). Job-search strategies and reemployment quality: The impact of career adaptability. Journal of Vocational Behavior, 77(1), 126-139.

Koestner, R., Losier, G. F., Vallerand, R. J., \& Carducci, D. (1996). Identified and introjected forms of political internalization: extending self-determination theory. Journal of personality and social psychology, 70(5), 1025.

La Cava, G., \& Simon, J. (2005). Household debt and financial constraints in Australia. Australian Economic Review, 38(1), 40-60.

Lalive, R. (2007). Unemployment benefits, unemployment duration, and post-unemployment jobs: A regression discontinuity approach. The American economic review, 108-112.

Lalive, R., Ours, J. C., \& Zweimüller, J. (2005). The effect of benefit sanctions on the duration of unemployment. Journal of the European Economic Association, 3(6), 1386-1417.

Leach, L., Butterworth, P., Rodgers, B., \& Strazdins, L. (2010). Deriving an evidence-based measure of job quality from the HILDA Survey. Australian Social Policy Journal, (9). Manroop, L., \& Richardson, J. (2015). Job Search: A Multidisciplinary Review and Research Agenda. International Journal of Management Reviews. doi: 10.1111/ijmr.12066 
McKee-Ryan, F.M., Song, Z., Wanberg, C. R., \& Kinicki, A. J. (2005). Psychological and physical well-being during unemployment: a meta-analytic study. Journal of applied psychology, 90(1), 53.

Miserandino, M. (1996). Children who do well in school: Individual differences in perceived competence and autonomy in above-average children. Journal of Educational Psychology, 88(2), 203.

Mortensen, D. T. (1977). Unemployment insurance and job search decisions. Industrial \& Labor Relations Review, 30, 505-517.

Mortensen, D. T. (1986). Job search and labor market analysis. In: Ashenfelter, O., Layard, R. (eds.), Handbook of labor economics, Vol II, 849-919.

Nekoei, A., \& Weber, A. (2015). Does Extending Unemployment Benefits Improve Job Quality? IZA DP No. 9034

Osterman, P. (2013). Introduction to the special issue on job quality: What does it mean and how might we think about it?. Industrial \& Labor Relations Review, 66(4), 739-752.

Petrongolo, B. (2009). The long-term effects of job search requirements: Evidence from the UK JSA reform. Journal of Public Economics, 93, 1234-1253.

Phillips, D. C. (2014). Getting to work: Experimental evidence on job search and transportation costs. Labour Economics, 29, 72-82.

Schmieder, J. F., von Wachter, T., \& Bender, S. (in press). The Effect of Unemployment Benefits and Nonemployment Durations on Wages, The American Economic Review.

Seguin, C., Pelletier, L. G., \& Hunsley, J. (1998). Toward a model of environmental activism. Environment and Behavior, 30(5), 628-652.

Summerfield, M., Freidin, S., Hahn, M., Li, N., Macalalad, N., Mundy, L., Watson, N., Wilkins, R. \& Wooden, M. (2014). HILDA User Manual-Release 13. Melbourne Institute of 
Applied Economic and Social Research.

Svarer, M. (2011). The effect of sanctions on exit from unemployment: Evidence from Denmark. Economica, 78(312), 751-778.

Tatsiramos, K., \& Ours, J. C. (2014). Labor market effects of unemployment insurance design. Journal of Economic Surveys, 28(2), 284-311.

Ullah, P. (1990). The association between income, financial strain and psychological well-being among unemployed youths. Journal of Occupational Psychology, 63(4), 317-330.

Van den Berg, G. J. (1990). Nonstationarity in job search theory. The review of economic studies, $57(2), 255-277$.

Van den Berg, G. J., Van der Klaauw, B., \& Van Ours, J. C. (2004). Punitive sanctions and the transition rate from welfare to work. Journal of Labor Economics, 22(1), 211-241.

Van der Klaauw, B., \& Van Ours, J. C. (2013). Carrot And Stick: How Re-Employment Bonuses And Benefit Sanctions Affect Exit Rates From Welfare. Journal of Applied Econometrics, $28(2), 275-296$.

Van Ours, J. C., \& Vodopivec, M. (2008). Does reducing unemployment insurance generosity reduce job match quality?. Journal of Public Economics, 92(3), 684-695.

Vansteenkiste, M., Lens, W., De Witte, S., De Witte, H., \& Deci, E. L. (2004). The ‘why’ and 'why not' of job search behaviour: their relation to searching, unemployment experience, and well-being. European Journal of Social Psychology, 34(3), 345-363.

Vansteenkiste, V., Lens, W., Witte, H., \& Feather, N. T. (2005). Understanding unemployed people's job search behaviour, unemployment experience and well-being: A comparison of expectancy-value theory and self-determination theory. British Journal of Social Psychology, 44(2), 269-287. 
Vansteenkiste, M., \& Van den Broeck, A. (in press). Understanding the motivational dynamics among unemployed individuals: Insights from the self-determination theory perspective. In U. C. Klehe, \& E. A. J. Van Hooft (Eds.), Handbook of job loss and job search. Oxford, UK: Oxford University Press. DOI: 10.1093/oxfordhb/9780199764921.013.005

Vinokur, A., \& Caplan, R. D. (1987). Attitudes and Social Support: Determinants of Job-Seeking Behavior and Well-Being among the Unemployed1. Journal of Applied Social Psychology, 17(12), 1007-1024.

Vinokur, A. D., \& Schul, Y. (2002). The web of coping resources and pathways to reemployment following a job loss. Journal of occupational health psychology, 7(1), 68.

Wanberg, C. R., Kanfer, R., \& Rotundo, M. (1999). Unemployed individuals: Motives, jobsearch competencies, and job-search constraints as predictors of job seeking and reemployment. Journal of Applied psychology, 84(6), 897.

Waters, L. E., \& Moore, K. A. (2001). Coping with economic deprivation during unemployment. Journal of economic psychology, 22(4), 461-482.

Welters, R., Mitchell, W., \& Muysken, J. (2014). Self determination theory and employed job search. Journal of Economic Psychology, 44, 34-44.

Williams, G. C., McGregor, H. A., Sharp, D., Levesque, C., Kouides, R. W., Ryan, R. M., \& Deci, E. L. (2006). Testing a self-determination theory intervention for motivating tobacco cessation: supporting autonomy and competence in a clinical trial. Health Psychology, 25(1), 91. 